\title{
EDUCATIONAL AND PHYSICAL TRAININGS WITH CHILDREN 11-12 and 13-14 YEARS OLD
}

\section{Jumanov 0.S.}

Ph.D., Associate Professor, Scientific And Methodological Provision Of Physical Education And Sports Specialists Under The Ministry Of Physical Training And Sports Of The Republic Of Uzbekistan

\section{ABSTRACT}

The author, on the basis of pedagogical observations carried out on volleyball players of 11-12 and 13-14 years old, is of particular importance to strengthening health, promoting the correct physical development of those involved, teaching them vital motor skills and abilities. This made it possible to successfully master the skills of playing volleyball to increase the effectiveness of technical and tactical actions in competitions.

KEYWORDS: - Volleyball, pedagogical observations, motor qualities, zones, motor skills, blocking, attacks, quickness.

\section{INTRODUCTION}

Specific pedagogical tasks follow from the general tasks that were outlined earlier. At the age of 11-12 and 13-14, health promotion, promotion of the correct physical development of the trainees, teaching them vital motor skills and abilities are of particular importance.

The tasks of special training in volleyball include;

- versatile physical training, first of all, the development of basic motor qualities, mainly quickness and dexterity, expansion of the motor experience of those involved;

-development of physical abilities specific to playing volleyball;

- teaching the basic techniques: receiving and passing the ball from above and below with two hands without falling and with falling, lower straight and upper feeds (direct and side), direct attacking blow, blow with transfer and lateral, blocking;

-training individual, group and team tactical actions in attack and defense.

These tasks vary depending on the stages of the educational and training process and on the age group.

There is a certain continuity in solving problems in the children's group (11-12 years old) and adolescent (13-14 years old). Let's give an example. At the age of 11-12, students must master the basics of the lower straight and upper 
CURRENT RESEARCH JOURNAL OF PEDAGOGICS 2(8): 87-91, August

2021 DOI: https://doi.org/10.37547/pedagogics-crjp-02-08-20

ISSN 2767-3278

(C)2021 Master Journals

Crossref dof 81 Google

Accepted 26 $6^{\text {th }}$ August, 2021 \& Published 31 ${ }^{\text {th }}$ August, 2021

straight serve techniques and be able to confidently send the ball into the court, observing the rules of the game.

At the age of 13-14, trainees should already be able to send the ball to any of the six zones
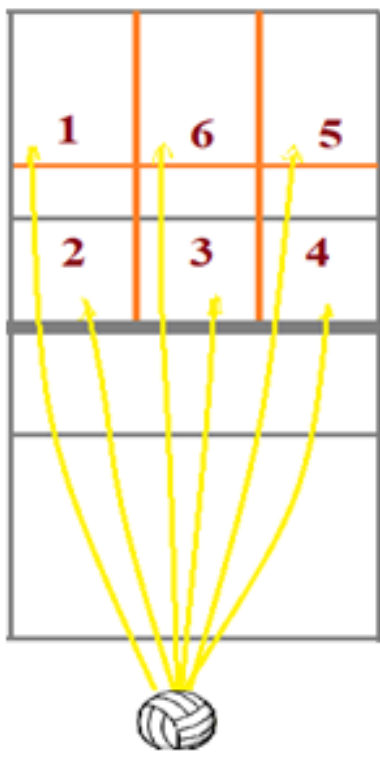

with the lower serve, and into any of the three corridors with the upper serve.

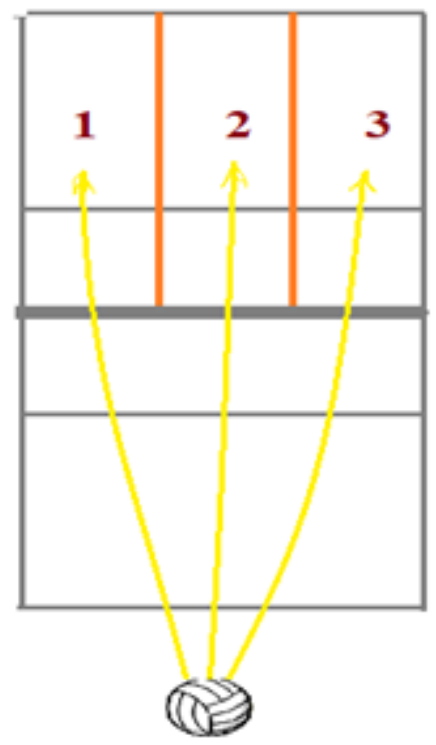


CURRENT RESEARCH JOURNAL OF PEDAGOGICS 2(8): 87-91, August

2021 DOI: https://doi.org/10.37547/pedagogics-crjp-02-08-20

ISSN 2767-3278

(C)2021 Master Journals

\section{Crossref do) 81 Google}

Accepted 26 th August, 2021 \& Published 31 ${ }^{\text {th }}$ August, 2021

In addition, at the age of 13-14, one must be able to serve the ball sufficiently strongly. Another example, In the first year of classes at the age of 11-12, students study preparatory and leading exercises for mastering the attacking strike technique and master the basics of hitting technique in simplified conditions, in the second year of training, trainees already perform a direct attacking blow and with the help of preparatory and leading exercises prepare for mastering technique of attacking blow with transfer and side impact. At the age of 13-14, trainees must already master the basics of the technique of all attacking strikes, so that in the future, at the age of 15-16, they are perfectly able to perform them.

The organization of educational work with children 11-14 years old (especially 11-12 years old) has some differences in comparison with the organization of work with older students.

Firstly, the interests of older schoolchildren are more persistent, and their desire to play volleyball is justified precisely by these interests. In children of 11-14 years old, and especially 1112 years old, interests are less stable, the desire to play volleyball is more based on a spontaneous craving for volleyball. Therefore, at this age, especially at the initial stage of training, it is very important to interest children in classes and instill in them a love of volleyball.

Secondly, working with older children, it is easier to determine their ability to play volleyball by physical development, by the level of development of physical abilities necessary for playing volleyball, and by other indicators. While coaching young children, especially 11-12 years old, it is much more difficult to answer the question of how they will master volleyball, what prospects await them in the future.

For a children's and youth sports school, whose pupils must master high sports and technical skills, the correct recruitment of educational troupes, and especially the initial selection of those involved in a children's group, is of great importance. The selection of children based on the results of observation of them in the game of volleyball cannot be acceptable for the age of 1112 years and, perhaps, even for an older age.

Many years of experience of the author of this section of the manual with young volleyball players and special experiments allow us to give some recommendations on the issue of recruiting training groups for volleyball for children of 11-12 years old.

It was found that children who at the beginning of the experiment (at the age of 11-12) had higher morph-physiological indicators and results in control tests retained these advantages in the future, as their age increased. Indicators of physical development, in particular growth data, as a rule, persist with age. This means that children, who had growth data above the average level at 11-12 years old, and at 17-18 years old, will also have a level of growth rates above the average.

This makes it possible, when recruiting training groups, to rely on objective indicators by which one can judge the presence of the ability to successfully master the skills of playing volleyball. However, it is known that human abilities develop in the activity in which they are applied. Therefore, it is possible to judge the ability of children to play volleyball only by starting to teach them how to play. Here, the main indicator will be how quickly the practitioners master the technique of the game, tactical actions, etc.

In the process of recruiting study groups, three stages can be distinguished.

In the first stage, a large campaign is carried out in order to arouse children's interest in volleyball, each candidate is thoroughly studied 
CURRENT RESEARCH JOURNAL OF PEDAGOGICS 2(8): 87-91, August

2021 DOI: https://doi.org/10.37547/pedagogics-crjp-02-08-20

ISSN 2767-3278

(C)2021 Master Journals

Crossref do: 81 Google

Accepted $26^{\text {th }}$ August, 2021 \& Published 31 th August, 2021

(health status, living conditions, interests, attitude of parents to sports, etc.).

The second stage is a system of trials (tests) and observations in order to obtain data by which one could judge the ability to successfully master the skills of playing volleyball.

At the third stage, in the process of teaching children the technique and tactics of the game, it is checked, the mastery of technical techniques and tactical actions takes place somewhat quickly. This is one of the main indicators of the ability to successfully master the skills of playing volleyball.

\section{References}

1. Volkov L.P. Theory and methodology of children and youth sports. Kiev, Olympic Literature, 2002 .-- 294 p.

2. Hayrapetyants L.R. Volleyball. // Textbook for higher educational institutions. T .: Zarqalam. 2006 .-- 240 p.

3. Belyaev A.V. Teaching the technique of playing volleyball and improving it. // Toolkit. Olympia. Man, Moscow: 2008 .-$54 \mathrm{p}$.

4. Garipov A.T., Kleschev Yu.Yu., Fomin E.V. Speed-strength training of young volleyball players. //Guidelines. VFV, M .: 2009 .-- 45s.

5. Zheleznyak Yu.D., Chachin A.V., Syromyatnikov Yu.P. Volleyball. // Sample programs for CYSS and SDYUSHOR. Soviet sport, M.: 2009.130s.

6. Abdullaeva B.P. Corruption in the field of education: assessments and ways to address. “Тенденции и перспективи развития науки и образования

в условиях

глобализации".Международной

научно-практической

интернет-

конференции.

Украина.2020 год 30

7. Abdullaeva B.P. Babaraximova B.P. Pardaev B.P.Using information and communication technologies in teaching process of various primary European Journal of Research and Reflection in Educational Sciences, 8 (10), 67-70. Progressive Academic Publishing, UKwww.idpublications.org 14.10.2020.

8. Abdullaeva B.P. Abdullaev F.T. Organization of Swimming Lessons In Preschool Institutions THE AMERICAN JOURNAL OF SOCIAL SCIENCE AND EDUCATION INNOVATIONS. JULY 2020[ TAJSSEI]322ISSN (e):2689-100X DOI: https://doi.org/10.37547/tajssei/Volu me02Issue 07-423.

9. Abdullayeva, B.P., \& Babaraximova, B. P. (2020). MAKTABGACHA TA'LIM MUASSASASIDA

FUTBOL DARSLARINI TASHKIL ETISH METODIKASI. Academic Research in Educational Sciences http://ares.uz/jurnallar-sahifasi/aresvol-1-no-3-2020.

10. Abdullaeva B.P. ACADEMICIA: An International Multidisciplinary Research Journal https://saarj.com ORGANIZATION AND METHODOLOGY OF CONDUCTING FOOTBALL LESSONS IN A PRESCHOOL INSTITUTION 650-655 10.5958/22497137.2021.00098.

11. Abdullaeva B.P. Teaching A Child To Play Football From A Youth. The 
CURRENT RESEARCH JOURNAL OF PEDAGOGICS 2(8): 87-91, August

2021 DOI: https://doi.org/10.37547/pedagogics-crjp-02-08-20

ISSN 2767-3278

(C)2021 Master Journals

Crossref dof 81 Google

Accepted 26 $6^{\text {th }}$ August, 2021 \& Published 31 ${ }^{\text {th }}$ August, 2021

American Journal of Interdisciplinary Innovations and Research (ISSN-26427478)Published:April302021Pages:147

151Doi:https://doi.org/10.37547/tajiir

/Volume03Issue04-24MPACT

FACTOR2021:5.6760CLC-1091588944. 